\title{
SINTESIS NANOKOMPOSIT LEMPUNG BENTONIT-ASAM SALISILAT DENGAN METODE SOL-GEL DAN KARAKTERISASINYA DENGAN XRD DAN IR-FTIR
}

\author{
Ida Ayu Gede Widihati*, Ni Putu Diantariani dan Ni Made Puspawati \\ Program Studi Kimia FMIPA Universitas Udayana, Bukit Jimbaran, Badung, Bali 80361 \\ *Email: gede_widihati@unud.ac.id
}

\begin{abstract}
ABSTRAK
Dalam penelitian ini dilakukan sintesis nanokomposit lempung bentonit-asam salisilat dengan metode sol gel melalui mekanisme interkalasi. Pada proses interkalasi ini, asam salisilat harus dibuat dalam bentuk senyawa kompleks dengan ion Fe(III) agar asam salisilat dapat masuk ke ruang antar lapis lempung. Pada proses interkalasi tahap pertama, konsentrasi interkalat divariasikan dengan tujuan mendapatkan nanokomposit yang memliki karakter kimia fisik yang terbaik. Sifat kimia fisik nanokomposit lempung bentonit-asam salisilat dikarakterisasi dengan menggunakan metode difraksi sinar X, FTIR. Pada tahap kedua dilakukan proses interkalasi dengan waktu reaksi yang bervariasi. Dari data XRD didapatkan bahwa variasi konsentrasi interkalat tidak menyebabkan perubahan kristalinitas yang signifikan. Ketiga komposit yang terbentuk menunjukkan puncak difraktogram yang sama dengan bentonit awal. Interkalasi asam salisilat ke dalam ruang antar lapis lempung bentonit menyebabkan peningkatan jarak antar lapis (d basal spacing) menjadi 16-17Å. Dari spektra IR dapat dilihat beberapa pita absorpsi yang karakteristik untuk lempung dan modifikasinya. Pita serapan pada bilangan gelombang $3620 \mathrm{~cm}^{-1}$ menunjukkan vibrasi stretching dari -OH untuk Al-OH pada montmorillonit. Bilangan gelombang $1640 \mathrm{~cm}^{-1}$ mengindikasikan adanya $-\mathrm{OH}$ bending dari air yang terabsorpsi. Pada ketiga spektra di atas terjadi pergeseran bilangan gelombang ke, (a). $1631,78 \mathrm{~cm}^{-1}$ (b). $1635,64 \mathrm{~cm}^{-1}$ dan (c). $1633,7 \mathrm{~cm}^{-1}$. Pita serapan pada bilangan gelombang $1115 \mathrm{~cm}^{-1}$ mengindikasikan adanya Si-O stretching untuk lapisan-lapisan silikat. Pada nanokomposit yang dihasilkan terjadi pergeseran bilangan gelombang tersebut ke 1109,7 $\mathrm{cm}^{-1}$ (a), $1111 \mathrm{~cm}^{-1}$ (b dan c). Pita serapan pada bilangan gelombang $1633,71 \mathrm{~cm}^{-1}, 1631,78 \mathrm{~cm}^{-}$ ${ }^{1}$ dan $1635 \mathrm{~cm}^{-1}$ pada ketiga spectra di atas menunjukkan adanya vibrasi dari gugus $\mathrm{C}=\mathrm{O}$ yang berasal dari asam salisilat. Adanya pita serapan pada bilangan gelombang $920 \mathrm{~cm}^{-1}$ mengindikasikan vibrasi bending dari Al-Al-OH. Karakterisasi dengan FTIR menunjukkan bahwa pemanasan dari $120^{\circ} \mathrm{C}$ hingga $250^{\circ} \mathrm{C}$ tidak mengakibatkan perubahan struktur yang ditunjukkan dengan tidak adanya pergeseran pita vibrasi yang dimilki oleh masing-masing gugus fungsi dari nanokomposit lempung bentonit asam salisilat
\end{abstract}

Kata kunci: asam salisilat, bentonit, nanokomposit, sintesis, karakterisasi

\begin{abstract}
This research concerned on the synthesis of bentonite clay-salicylic acid nanocomposite with the sol gel method through intercalation mechanism. In the intercalation process, salicylic acid must be made in the form of complex with ion $\mathrm{Fe}$ (III), this was to cause salicylic acid could get into the space between the layers of clay therefore. In the first stage of intercalation process, the concentration of intercalated was varied to achieve the best physico-chemical characteristics of the nanocomposite. The physico-chemical properties of bentonite clay nanocomposite-salicylic acid were characterized using X-ray diffraction (XRD), FTIR. Analysis of the XRD data showed that the variations in the concentration of intercalated one did not significantly change crystallinity. All of the composites formed showed the same diffractogram peaks to the initial bentonite. The intercalation of salicylic acid into the space between the bentonite clay layers caused the distance between layers ( $\mathrm{d}$ basal spacing) increased to $16-17 \AA$. The analysis of the spectra of infrared (IR) showed there were several characteristic absorption bands of clay and its modification. The absorption band at the wave number of $3620 \mathrm{~cm}^{-1}$ assigned for stretching vibration of $\mathrm{OH}$ to $\mathrm{Al}-\mathrm{OH}$ on montmorillonite, the band at $1640 \mathrm{~cm}^{-1}$ indicated the presence of $\mathrm{OH}$ bending from water adsorbed. Infrared spectra of the three nanocomposites formed shifted to a lower wave number to (a). $1631.78 \mathrm{~cm}^{-1}$, (b) $1635.64 \mathrm{~cm}^{-1}$ and (c), $1633.7 \mathrm{~cm}^{-1}$, respectively. The absorption band at the wave number of $1115 \mathrm{~cm}^{-1}$ indicated the $\mathrm{Si}-\mathrm{O}$ stretching for the silicate layers and all of the nanocomposite obtained shifted the $\mathrm{Si}-\mathrm{O}$ stretching silicate layers
\end{abstract}


to (a)., $1109.7 \mathrm{~cm}^{-1}$, (b and c) $1111 \mathrm{~cm}^{-1}$, respectively. The adsorbtion at the wavenumber of $1633.71 \mathrm{~cm}^{-1}, 1631.78$ $\mathrm{cm}^{-1}$ and $1635 \mathrm{~cm}^{-1}$ showed the vibration of $\mathrm{C}=\mathrm{O}$ groups derived from salicylic acid. The absorption band at the wave number of $920 \mathrm{~cm}^{-1}$ indicated the bending vibration of Al-Al-OH. From FTIR spectra, it was found that heating the nanocomposites from 120 to $250 \mathrm{oC}$ did not change its structure.

Keywords: bentonite, nanocomposite, salicylic acid, synthesis, characterization

\section{PENDAHULUAN}

Lempung adalah salah satu mineral alam yang keberadaannya sangat berlimpah. Pemanfaatan lempung di bidang kesehatan bukanlah hal yang baru. Di Perancis, tanah lempung yang dikenal dengan nama llite dimanfaatkan karena sifatnya yang mudah menyerap racun pada tubuh. Tanah lempung digolongkan sebagai mineral karena mengandung kalsium, aluminium, magnesium, silika, tembaga fosfor, dan zink. Praktisi pengobatan alternatif percaya komposisi ini membuat tanah liat hijau Perancis sangat bermanfaat sebagai pengobatan terapi untuk berbagai masalah kesehatan, dan merupakan salah satu dari lempung yang paling populer digunakan di Pelotherapy. Dalam bidang Farmasi Lempung digunakan sebagai excipient, shielding dan adsorben. Belakangan ini pemanfaatan lempung sebagai sistem penghantar obat( drug delivery system) banyak dikaji (Joshi et al., 2009; Javiera et al., 2015). Interaksi lempung dengan senyawa organik,merupakan fenomena yang kompleks karena melibatkan gaya van der waals, ikatan hidrogen, pertukaran ion, koordinasi dan kemisorpsi (Kubicki et al., 1997; Bonina et al., 2007).

Pada material nanokomposit lempung bentonit-asam salisilat yang dihasilkan, lempung berfungsi sebagai sistem penghantar obat (asam salisilat) yang dapat mengurangi efek toksisitas sitemik yang ditimbulkan akibat pemakaian asam salisilat yang berulang-ulang. Asam salisilat merupakan asam hidroksi benzoat yang termasuk ke dalam golongan obat anti inflamasi non steroid (OAINS) yang memiliki sifat sebagai senyawa anti-inflamasi, antiseptik, antiradikal, analgesik, antirematic, antioksidan, antikarsinogenik (Belsito et.al., 2007) Asam salisilat dipakai secara luas hampir di seluruh belahan dunia baik secara oral maupun secara topikal, Asam salisilat telah digunakan secara luas dalam terapi topikal sebagai bahan keratolitik. Zat ini merupakan bahan keratolitik tertua yang digunakan sejak 1874 (Lee and Kim, 2003). Berbagai penelitian menyimpulkan tiga faktor yang berperan penting pada mekanisme karetolitik asam salisilat yaitu menurunkan ikatan korneosit, melarutkan semen interselluler, dan melonggarkan serta mendisitegrasikan korneosit (Bashir et al., 2005; Leveque, 2002). Ciselia et al. (2014) meneliti efek teratogenik asam salisilat pada per-kembangan morfologi fetus mencit (Mus musculus L), didapatkan bahwa pemberian asam salisilat mulai dari dosis $40 \mathrm{mg} / \mathrm{kgBB}$ mencit dapat menurunkan jumlah implantasi dan juga jumlah fetus hidup, pemberian asam salisilat mulai dari dosis $80 \mathrm{mg} / \mathrm{kgBB}$ mencit dapat menyebabkan kematian janin (IUFD), pemberian asam salisilat mulai dari dosis 60 $\mathrm{mg} / \mathrm{kgBB}$ mencit menyebabkan kecacatan open eyelids (Ciselia et al., 2014).

Pada penelitian ini dilakukan interkalasi asam salisilat ke dalam ruang antar lapis silikat lempung dan diharapkan pengaruh struktur dan sifat mineral lempung memberikan efek yang bagus terhadap sifat asam salisilat yaitu mengurangi efek toksisitas sistemiknya. Pengaruh variabel konsentrasi interkalat (asam salisilat), $\mathrm{pH}$ dan temperatur kalsinasi perlu diteliti untuk mendapatkan kondisi optimum sintesis kompleks nanokomposit lempung-asam salisilat.

\section{MATERI DAN METODE}

\section{Bahan}

Bahan-bahan kimia yang digunakan dalam penelitian ini berkualitas pro analisis (p.a) diantaranya: Lempung Bentonit, natrium hidroksida $(\mathrm{NaOH})$, asam klorida $(\mathrm{HCl})$, $\mathrm{FeCl}_{3} .6 \mathrm{H}_{2} \mathrm{O}$, asam salisilat, $\mathrm{NaCl}, \mathrm{KCl}$, $\mathrm{MgCl}_{2}, \mathrm{CaCl} 2, \mathrm{AgNO}_{3}, \mathrm{HCl}, \mathrm{KH}_{2} \mathrm{PO}_{4}$, air bebas ion. Selain itu juga digunakan akuades dan kertas saring Whatman 42. 


\section{Peralatan}

Peralatan yang digunakan dalam penelitian ini adalah: alat-alat gelas, timbangan analitik, $\mathrm{pH}$ meter, pengaduk magnetik, pemanas, penggerus porselen, lumpang, ayakan 100 dan 250 mesh, oven, desikator, penyaring vakum, sentrifugasi, Seperangkat instrumentasi XRD dan FTIR.

\section{Cara Kerja}

\section{Preparasi lempung Bentonit}

Tigaratus gram lempung bentonit alam didispersikan dalam 1L larutan $\mathrm{NaCl} 0,1 \mathrm{M}$, diaduk selama 12 jam dan disentrifugasi, kemudian disaring dan dicuci dengan air bebas ion sampai benar-benar terbebas dari ion $\mathrm{Cl}^{-}$(uji negatif terhadap larutan $\mathrm{AgNO}_{3}$ ) (Bergaya,2006). Na-Bentonit yang dihasilkan dikeringkan pada $100-120^{\circ} \mathrm{C}$ dan digerus hingga ukurannya lolos ayakan 100 mesh.

\section{Sintesis nano komposit lempung bentonit-asam salisilat}

Sebanyak $30 \mathrm{~g}$ lempung bentonit yang telah dipreparasi (Na-Bentonit) disuspensikan ke dalam $600 \mathrm{~mL}$ larutan yang mengandung kompleks Fe(III)-Asam salisilat (Fe (III) 0,0176 M dan Asam salisilat 0,025M), diaduk dengan pengaduk magnetik selama 24 jam, kemudian disaring dengan penyaring vakum, dicuci dengan air bebas ion berkali-kali sampai seluruh ion $\mathrm{Cl}^{-}$ hilang yang ditunjukkan dengan uji negatif terhadap larutan $\mathrm{AgNO}_{3}$.Komposit yag dihasilkan selanjutnya dikeringkan dalam oven pada temperatur $110-120^{\circ} \mathrm{C}$. Untuk mengetahui pengaruh konsentrasi interkalat terhadap karakter nano komposit, konsentrasi Fe (III) dan asam salisilat dibuat dengan perbandingan $2 \mathrm{x} ; 3 \mathrm{x}$ konsentrasi awalnya. Untuk karakterisasi nano komposit dilakukan dengan instrument XRD dan FTIR.

\section{HASIL DAN PEMBAHASAN}

\section{Nanokomposit Lempung Bentonit-Asam Salisilat}

Tahap sintesis nanokomposit lempung bentonit- asam salisilat diawali dengan preparasi lempung bentonit yang dilakukan dengan tujuan menghilangkan pengotor yang melekat pada partikel lempung bentonit sehingga memudahkan proses interkalasi. Pencucian dan dekantasi memerlukan proses yang relatif lama (satu minggu dengan pelaksanaan 6 jam setiap hari) disebabkan karena sifat lempung yang mengikat air dengan sangat kuat.

Adsorpsi asam salisilat oleh mineral lempung sangat terbatas, di samping itu asam salisilat tidak terlalu larut dalam air (kelarutan air pada $20^{\circ} \mathrm{C}$ adalah $0,011 \mathrm{M}$, Pena et al., 2004) sedangkan pemanfaatan lempung sabagai bahan farmasetika memerlukan jumlah yang signifikan dari obat yang teradsorpsi. Karena alasan tersebut, supaya asam salisilat bisa teradsorpsi secara maksimal oleh lempung, asam salisilat direaksikan sebelumnya dengan $\mathrm{Fe}^{3+}$ (kation bervalensi tinggi) membentuk senyawa kompleks fe-salisilat. Asam salisilat merupakan kelator logam besi yang kuat membentuk kompleks kation di lingkungan berair yang bersifat asam (Del Hoyo et al., 1998).

Reaksi pembentukan kompleks Fe-salisilat mengikuti mekanisme sebagai berikut:

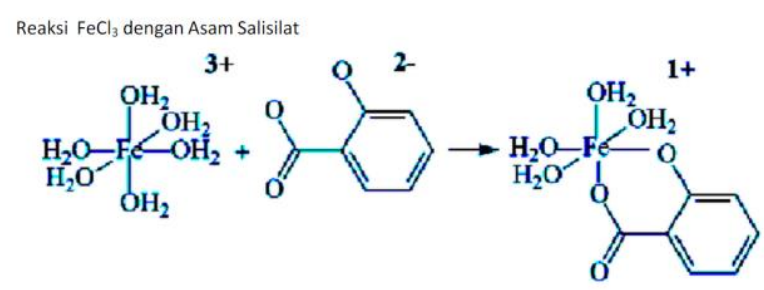

Pada tahap interkalasi ini digunakan konsentrasi interkalat $\left(\mathrm{FeCl}_{3}\right.$ dan asam salisilat) yang bervariasi dengan tujuan mendapatkan konsentrasi interkalat optimum yang menghasilkan nanokomposit dengan karakter yang terbaik. Setelah melalui proses pencucian, dekantasi, pengeringan dan pengayakan komposit yang dihasilkan dianalisis sifat kimia fisiknya seperti struktur kristal dengan metode difraksi sinar X, Pengaruh suhu pemanasan terhadap gugus fungsi yang ada pada material nanokomposit menggunakan dianalisis dengan menggunakan spektrofotometer infra merah.

\section{Karakterisasi dengan XRD}

Komposit lempung bentonit-asam salisilat dikarakterisasi dengan XRD untuk mengetahui kristalinitas komposit yang terbentuk, perubahan jarak antar lapis lempung bentonit, dan ukuran partikel dari komposit lempung bentonit-asam 
salisilat (Bonina, et al., 2007). Difrakto-gram dari lempung bentonit dan komposit lempung-bentonit asam salisilat dapat dilihat pada Gambar 1.

Dari difraktogram yang diperoleh dapat dijelaskan bahwa interkalasi kompleks asam salisilat ke dalam antar lapis lempung di ketiga variasi konsentrasi interkalat tidak menyebabkan perubahan kristalinitas yang signifikan. Puncak yang tajam di sudut $2 \theta=5,5$ yang merupakan karakteristik dari montmorillonit masih tetap ada di ketiga komposit lempung bentonit-asam salisilat yang terbentuk (komposit 1,2,dan3). Puncak yang tajam pada $2 \theta=26^{\circ}$ mengindikasikan adanya kristal kuarsa yang merupakan salah satu komponen bentonit.

Kompleks Fe(III)-Salisilat yang biasanya menunjukkan puncak yang tajam pada $2 \theta=35$, pada difraktogram ini intensitasnya tidak terlalu tajam namun tetap tetap ada pada sudut tersebut. Tidak tajamnya puncak Fe(III)-salisilat, kemungkinan disebabkan karena keberadaannya bukan sebagai kristal tunggal namun sebagai komposit dari bentonit sehingga berpengaruh terhadap keajegan struktur kristalnya.
Dari ketiga komposit yang terbentuk, difrakto-gram komposit 3 (konsentrasi $\mathrm{Fe}$ (III) paling besar) menunjukkan puncak yang tajam pada sudut $2 \theta=26^{\circ}$ dengan intensitas $100 \%$ yang merupakan identitas bidang (011) dari asam salisilat dan keberadaan kristal kuarsa (JCPDS). Natural montmorillonit menunjukkan refleksi $\mathrm{d}_{001}$ (d spacing $=$ jarak antar lapis) sebesar 13,9 . Interkalasi kompleks $\mathrm{Fe}$ (III)-Asam salisilat menyebabkan jarak antar lapis meningkat menjadi

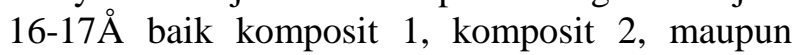
komposit 3.

Tabel 1.Peningkatan d spacing karena interkalasi $\mathrm{Fe}(\mathrm{III})$-Salisilat

\begin{tabular}{clcc}
\hline No & \multicolumn{1}{c}{ Sampel } & $\mathbf{2 \theta}$ & $\mathbf{d}(\mathbf{\AA})$ \\
\hline 1. & Bentonit & 5,9733 & 14,7841 \\
2. & Nanokomposit & 5,1707 & 17,0770 \\
& LBAS 1 & & \\
3. & Nanokomposit & 5,3165 & 16,6090 \\
& LBAS 2 & & \\
4. & Nanokomposit & 5,3200 & 16,5980 \\
& LBAS 3 & & \\
\hline
\end{tabular}

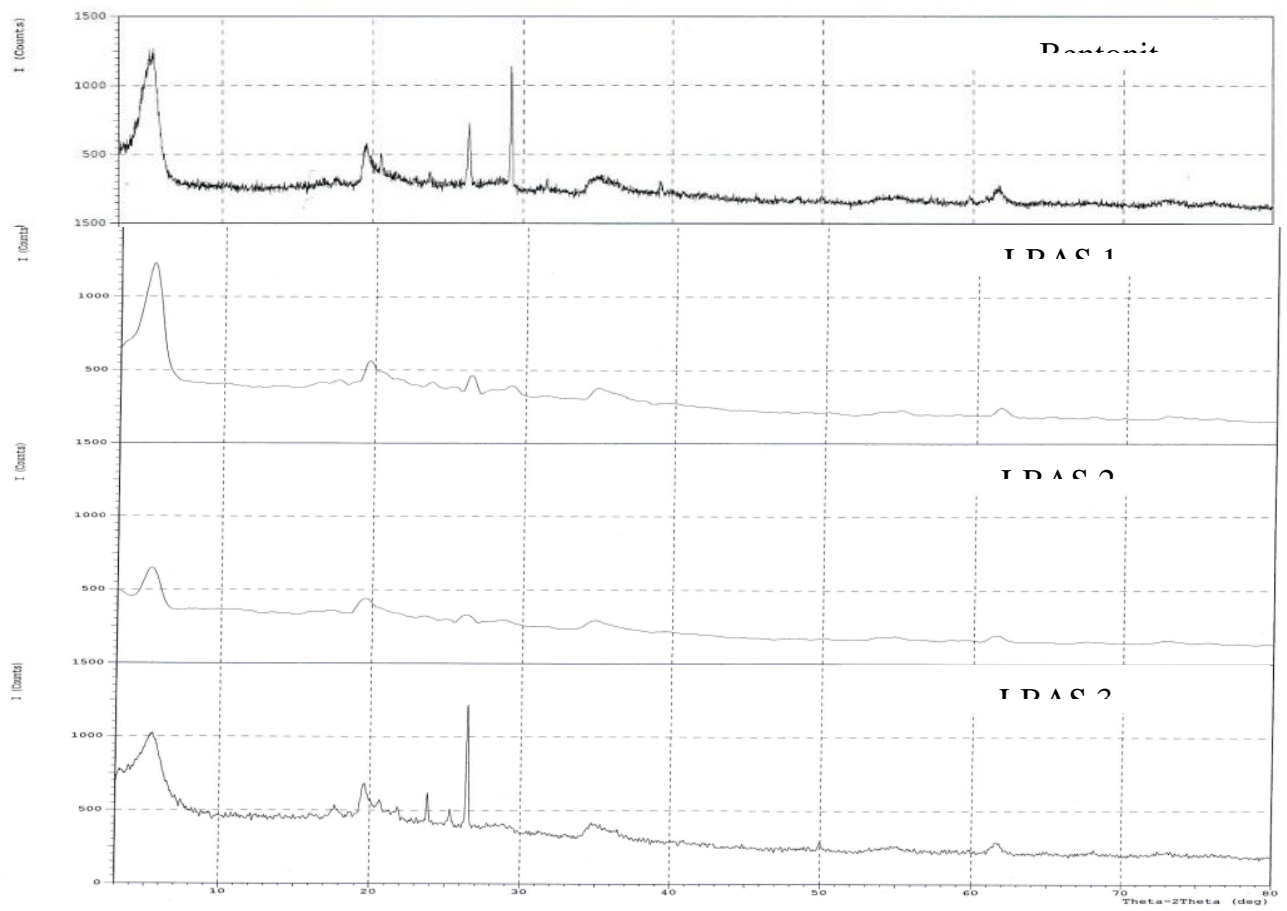

Gambar 1. Difraktogram komposit 


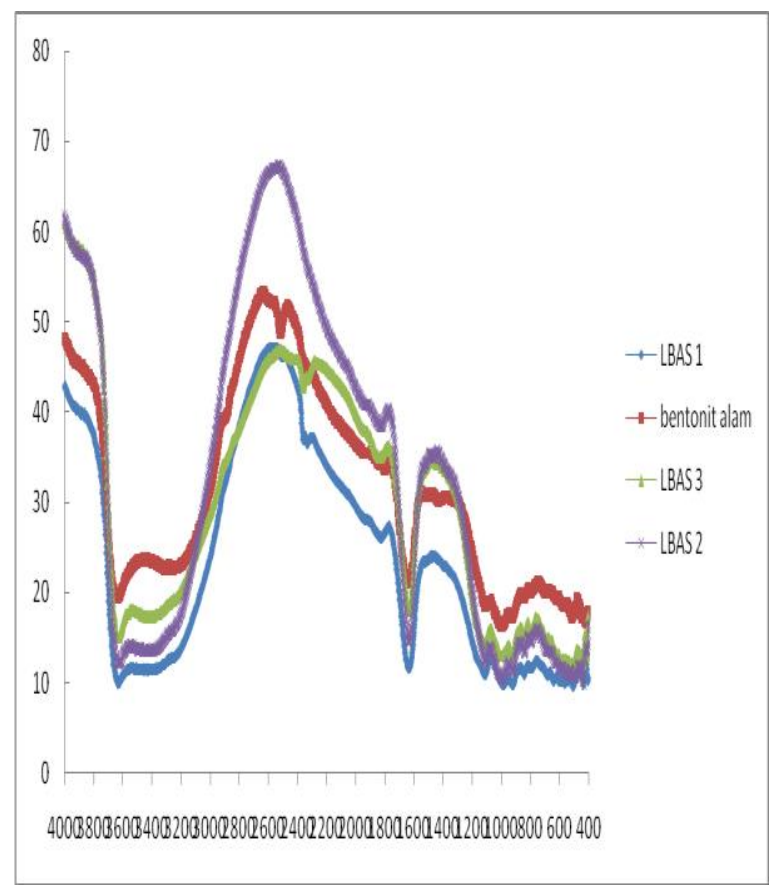

Gambar 2. Spektra IR-FTIR untuk nanokomposit LBAS $1,2,3$

\section{Karakterisasi nanokomposit dengan spektrofoto-meter Infra Merah (IR-FTIR)}

Spektrofotometer infra merah (IR-FTIR) diperlukan dalam karakterisasi nanokomposit yang dihasilkan untuk mengetahui gugus fungsi yang terbentuk setelah terjadinya proses interkalasi. Spektra IR bersifat karakteristik untuk masingmasing senyawa.

Dari spektra IR dapat dilihat beberapa pita absorpsi yang karakteristik untuk lempung dan modifikasinya. Pita serapan pada bilangan gelombang $3620 \mathrm{~cm}^{-1}$ menunjukkan vibrasi stretching dari $-\mathrm{OH}$ untuk $\mathrm{Al}-\mathrm{OH}$ pada montmorillonit. Bilangan gelombang $1640 \mathrm{~cm}^{-1}$ mengindikasikan adanya $-\mathrm{OH}$ bending dari air yang terabsorpsi, pada ketiga spektra di atas terjadi pergeseran bilangan gelombang ke, $1631,78 \mathrm{~cm}^{-1}$ (a) $1635,64 \mathrm{~cm}^{-1}$ (b) dan $1633,7 \mathrm{~cm}^{-1}$ (c). pita serapan pada bilangan gelombang $1115 \mathrm{~cm}^{-1}$ mengindikasikan adanya $\mathrm{Si}-\mathrm{O}$ stretching untuk lapisan-lapisan silikat. Pada nanokomposit yang dihasilkan terjadi pergeseran bilangan gelombang tersebut ke 1109,7 $\mathrm{cm}^{-1}(\mathrm{a}), 1111 \mathrm{~cm}^{-1}$ (b dan c). Pita serapan pada bilangan gelombang 1633,71 $\mathrm{cm}^{-1}, 1631,78 \mathrm{~cm}^{-1}$ dan $1635 \mathrm{~cm}^{-1}$ pada ketiga spectra di atas menunjukkan adanya vibrasi dari gugus $\mathrm{C}=\mathrm{O}$ yang berasal dari asam salisilat. Pita serapan pada bilangan gelombang $920 \mathrm{~cm}^{-1}$ mengindikasikan vibrasi bending dari $\mathrm{Al}-\mathrm{Al}-\mathrm{OH}$.

\section{Pengaruh suhu terhadap spektra IR nanokomposit lempung bentonit asamSalisil at \\ Untuk mempelajari pengaruh suhu} terhadap struktur nanokomposit lempung bentonitasam salisilat, komposit tersebut dipanaskan pada temperature yang bervariasi yaitu $120^{\circ} \mathrm{C}, 150^{\circ} \mathrm{C}$, $200^{\circ} \mathrm{C}$, dan $250^{\circ} \mathrm{C}$. Perubahan sifat yang terjadi akibat pemanasan dianalisis dengan menggunakan spektrofotometer IR-FTIR.

Dari keempat variasi suhu pemanasan yang diberikan ternyata tidak ada perubahan spektrum IR yang signifikan. Hampir semua pita vibrasi muncul di bilangan gelombang yang sama, pergeseran bilangan gelombang yang relatif sedikit terjadi di beberapa situs pita vibrasi. Keadaan ini mengindikasikan bahwa perlakuan temperatur hingga $250^{\circ} \mathrm{C}$ tidak mengubah struktur dan komposisi nanokomposit yang terbentuk.

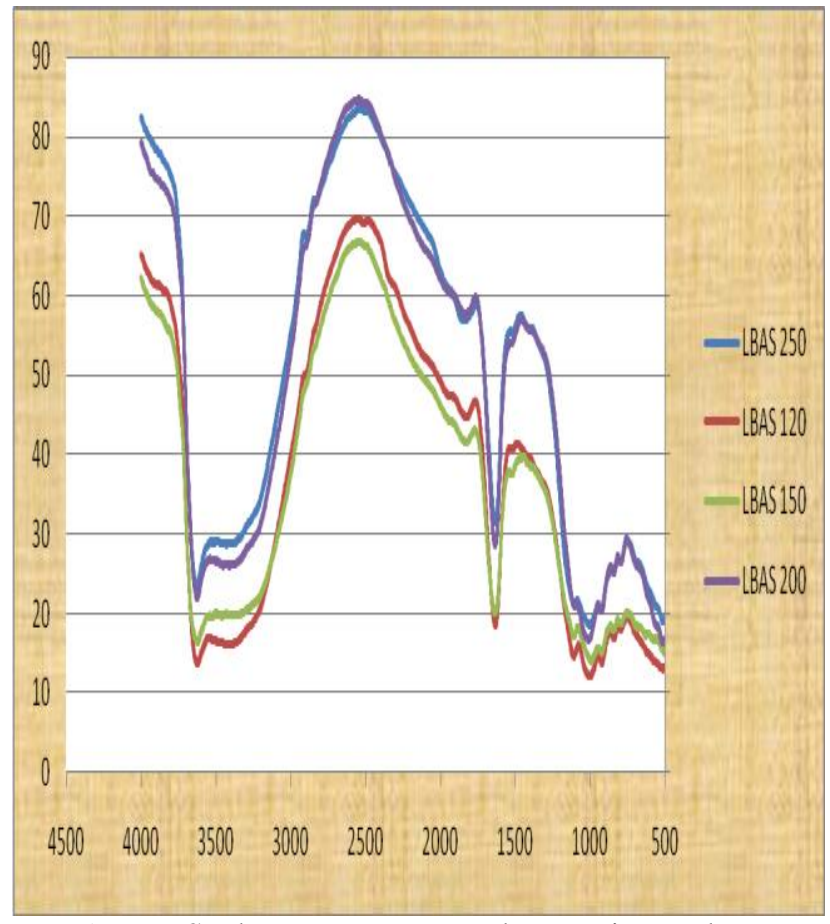

Gambar 3. Spektra FTIR nanokomposit dengan pemanasan $120^{\circ}, 150^{\circ}, 200^{\circ}$, dan $250^{\circ} \mathrm{C}$ SIMPULAN DAN SARAN 


\section{Simpulan}

Dari penelitian yang telah dilakukan dapat disimpulkan bahwa sintesis nanokomposit Lempung Bentonit-Asam Salisilat dengan metode sol gel melalui mekanisme interkalasi asam salisilat ke dalam ruang antar lapis lempung bentonit telah berhasil dilakukan. Hasil karakterisasi dengan XRD menunjukkan variasi konsentrasi interkalat tidak meyebabkan perubahan struktur kristalinitas yang signifikan. Interkalasi asam salisilat menyebabkan lempung bentonit mengalami kenaikan jarak antar lapis dari $14 \AA$ menjadi $17 \AA$. Karakterisasi dengan IR-FTIR menun-jukkan bahwa pemanasan dari $120^{\circ} \mathrm{C}$ hingga $250^{\circ} \mathrm{C}$ tidak mengakibatkan perubahan struktur yang ditunjukkan dengan masih ajegnya pita vibrasi yang dimilki oleh masing-masing gugus fungsi dari nanokomposit lempung bentonit asam salisilat

\section{UCAPAN TERIMA KASIH}

Terima kasih kepada LPPM Universitas Udayana yang telah memberikan dana penelitian melalui dana penelitian hibah bersaing dana DIKTI.

\section{DAFTAR PUSTAKA}

Aguzzi C., Cerezo P., Viseras C., and Caramella C., 2007, Uses of Clay Aas Drug Delivery Systems: Possibilities and Limitations, Journal of Applied Clay Science, 36: 2236

Bashir, S.J., Dreher, F., Chew, A.L., Zhai, H., Levin, C., and Stem, R., 2005, Cutaneous Bioassay of Salicylic Acid as a Keratolytic. Int., J. Pharmaceutics, 292: 187-94

Bonina, F.P.,,Giannossi, M.L., Medici, L., Puglia, C., Summa, V., and Tatco, F., 2007, Adsorption of Salicylic acid on bentonite and kaolin and release experiments,
Journal of Applied Clay Science, 36: 7785

Belsito, D., Bickers, D., Bruze, M., Calow, P., Greim, M., Hanifin, J.M. 2007. A toxicologic and dermatologic assessment of salicylic acid when used as fragrance ingredients. J Food and Chemical Toxicology. 45: 318-61

Ciselia D., Setiawan A., Nita, S., dan Salni, 2014, Efek Teratogenik Asam Salisilat pada Perkembangan Morfologi Fetus Tikus Mencit (Mus musculus L.) Swiss Webster, Jurnal Penelitian Sains, 17 (1): 35-43

Del Hoyo, C., Vicente, M.A., and Rivers, V., 1998, Application of Phenyl salicylatesepiolite system as ultraviolet radiation fibers, Clay Minerals, 33: 467-474

Javiera, C.S., Antonio, N.C., Maria, T.R., Virginia, G.V., Eduardo, P. 2015. Antiinflammatory, anti-bacterial, and cytotoxic activity of fibrous clays. Journal of Colloids and surfaces B: Biointerfaces. 6927-7765.

Joshi G.V., Kevadiya, B.D., Patel, H.A., Bajaj H.C., and Jasra, R.V., 2009, Montmorillonite as a drug delivery system: Intercalation and in vitro release of timolol maleate, International Journal of Pharmaceutics, 374: 53-57

Kubicki, I.D., Ith, M.J., Schrocter, L.M., and Apitz, S.E., 1997. Bonding Mechanism of Salycilic Acid adsorbed onto illite Clay: an ATR-FTIR and Molecular Orbital study, Environmental Science and Technology, 31: 1151-1156

Lee, H.S. and Kim, I.H., 2003, Salicylic Acid peels for The Treatment of Acne Vulgaris in Asian Patient, Dermatolog Surg, 29: 1196

Leveque, J.L. and Saint-Leger, D., 2002, Salicylic Acid and Derivatives, In: Leyden JJ, Rawlings AV, Editor, Skin Moisturiation, Marcel Dekker, New York, 2130-2137 